Selcuk Journal of Agriculture and Food Sciences

http://sjafs.selcuk.edu.tr/sjafs/index

Research Article
SJAFS

(2020) 34 (2), 132-136

e-ISSN: 2458-8377

DOI:10.15316/SJAFS.2020.206

\title{
The Estimation of Trypsin Inhibitor Activities in Soybean Meals Produced in Turkey*
}

(iD)Renan ŞEKER ${ }^{1, *}$, (DŞakir Doğan TUNCER ${ }^{2}$

${ }^{1}$ Necmettin Erbakan University, Faculty of Education, Department of Science Education, Konya, Turkey

${ }^{2}$ Ankara University, Faculty of Veterinary Medicine Department of Animal nutrition. Retired lecturer, Ankara, Turkey

\begin{tabular}{l}
\hline ARTICLE INFO \\
\hline Article history: \\
Received date: 07.02 .2020 \\
Accepted date14.05.2020 \\
\hline Edited by: \\
İbrahim AYTEKİN; Selçuk University, \\
Turkey \\
Reviewed by: \\
Yusuf CUFADAR; Selçuk University, \\
Turkey \\
Halit İMIK; Atatürk University, Turkey \\
\hline
\end{tabular}

Keywords:

Soybean Meal,

Trypsin Inhibitor Activity

Urease Activity

\begin{abstract}
This study was conducted in order to determine the nutrient contents and some anti-nutritional factors of of soybean and soybean meal produced in the Adana province of Turkey and imported from various countries. Totally 8 samples, consisting of 5 soybean meals, 1 full-fat soybean meal, 2 raw soybeans, were used in this study as research materials. The trypsin inhibitor activities (TIA) and urease activities (UA) were determined as anti-nutritional factors. Additionally, the degrees of changes in these factors were analyzed in the soybeans which were exposed to heat, humidity and pressure. Besides, the cresol red (CR) test was used to estimate the toasting degree of the samples and to compare with other analysis results. The average TIA, UA and CR values in soybean meal of the soya produced in Turkey used in the experiment, were found to be $2.59 \mathrm{mg} / \mathrm{g}, 0.05 \mathrm{mg} \mathrm{N} / \mathrm{g} /$ minute and $4.39 \mathrm{mg} / \mathrm{g}$, respectively. TIA, UA and $\mathrm{CR}$ values are determined for the imported soybean meal are $1.62 \mathrm{mg} / \mathrm{g}$, $0.082 \mathrm{~N} / \mathrm{g} /$ minute and $4.45 \mathrm{mg} / \mathrm{g}$ respectively. These values are in the same order for for full-fat soybean, $9.60 \mathrm{mg} / \mathrm{g}, 0.071 \mathrm{mg} \mathrm{N} / \mathrm{g} /$ minute and $4.43 \mathrm{mg} / \mathrm{g}$. TIA values of raw soybean (1) which were autoclaved for 35 minutes at $100^{\circ} \mathrm{C}$, $110^{\circ} \mathrm{C}, 120^{\circ} \mathrm{C}$ and $130^{\circ} \mathrm{C}$ were found as $23.20,10.27,2.91,0.53$ and $0.20 \mathrm{mg} / \mathrm{g}$ respectively. UA values for same raw soybeans were detected as 8.40, 2.36, $0.23,0.00$ and $0.00 \mathrm{mg} \mathrm{N} / \mathrm{g} / \mathrm{min}$ and CR values were found as $2.42,2.42,4.22$, 4.46 and $4.95 \mathrm{mg} / \mathrm{g}$ respectively. TIA values were 30.00, 27.12, 26.74, 26.29 and $22.74 \mathrm{mg} / \mathrm{g}$ in the raw Soybean sample that was subjected to dry heat (heated at $100^{\circ} \mathrm{C}, 110^{\circ} \mathrm{C}, 120^{\circ} \mathrm{C}, 130^{\circ} \mathrm{C}$ ). In the raw soybean sample, where dry heat was applied, the UA values were started with no heat applied, respectively, 8.87, 8.87, 8.80, 8.75 and $4.62 \mathrm{mg} \mathrm{N} / \mathrm{g} / \mathrm{min}$; CR values were found as $3.03,3.07,3.07,3.22$ and $3.28 \mathrm{mg} / \mathrm{g}$ in the same order.
\end{abstract}

\section{Introduction}

Animal products such as meat, milk and eggs are among the most essential foodstuffs for the world's rapidly growing population to ensure adequate and balanced nutrition. Optimizing animal production is directly related to sufficient and balanced nutrition of livestock. Maintaining the balance of amino acids in poultry and monogastric animals, which have to take exogenous amino acids from the feed, is very important in terms of nutrition. In our country, inadequate production of animal-origin feeds, which are rich in exogenous amino acids, causes problems in balancing rations of animals. Thus, the soybean, which contains a high level of protein and appropriate amino acid balance and the soybean meal, which is produced using

\footnotetext{
*Corresponding author email: rseker@erbakan.edu.tr *This study was produced from Master's thesis of Renan ŞEKER
}

soybean, became an alternative to animal-origin feed ingredients (Liu, 2004).

Although it is possible to eliminate the antinutrients during processing in the soybean plant, which plays an important role in human and animal nutrition, some of these substances may be passed on to the product in plants which are not properly processed. Analysis such as trypsin inhibitor activity (TIA), urease activity (UA) and dye binding test are the main methods used to determine the quality of these compounds in soybean (Hamerstrand, Black and Glover, 1981; Garlich, 1987; Holmes 1987).

When this study was conducted, soybean production in the world was calculated as 100 million tons and more than half of this amount was produced in USA (Aygar, 1987). Soybean production was reported to be 314 million tons in 2016 (Taşcı and Uçum, 2018). While USA ranked first in the world soybean production amount, it had 106.8 million tons of production in 2015/16 season. Brazil ranked second with 96.5 million 
tons, Argentina ranked third with 56.8 million tons, China ranked fourth with 11.8 million tons and India ranked fifth with 6.9 million tons (Taşc1 and Uçum, 2018). While soybean production in Turkey was 120 000 tons (Anonymous, 1988), 165000 tons of soybean were grown in 381804 decares in 2016 (Taşc1 and Uçum, 2018).

Soybean has the richest protein among oilseed grains. Most of the proteins in the structure are composed of globulins (Morrison, 1961; Koshiyama et al., 1981). Soybean protein is similar to casein and is therefore also referred to as vegetable casein. Soybean meal has a very stable amino acid composition for monogastric animals. It is especially rich in lysine, which is insufficient in many feed ingredients. However, when only soybean protein is used as a protein source, methionine deficiency is frequently encountered (Becker and Nehring, 1965).

Like most oilseeds, raw soybean has anti-nutritional substances that negatively affects feed conversion and animal production. Trypsin inhibitors, urease, hemagglutinin and lipoxidase are the leading anti-nutritional factors found in the structure of soybean. Temperature, humidity, pressure and chemicals can eliminate the effects of these substances (Balloun, 1980).

Various tests are used to determine the quality of soybean and soybean meal. Measuring the amount of trypsin inhibitor activity is the most significant one (Hamerstrand et al., 1981). A high amount of TIA indicates insufficient heat and time applied in the process. Since the method is difficult and time consuming, urease activity estimations, which are easier to perform in laboratory, are used for this purpose (Garlich, 1987). In order to determine the height of the applied heat, dye binding test is used (Holmes, 1987).

This study was conducted to determine the nutrient contents and levels of anti-nutritional factors in soybean and soybean meal produced in the Adana province of Turkey and compare those with imported soybean and its meal. Therefore, it is expected that this study may contribute to our country's feed industry and animal husbandry.

\section{Materials and Methods}

\subsection{Material}

In this study, total samples consisting of 4 soybean meals produced in factories in Turkey, 1 soybean meal imported from the United States, 2 raw soybeans (raw soybean 1 and 2) and 1 full-fat soybean, were used as materials.

\subsection{Processes applied to the material}

Samples with high oil content were extracted with ether and the oil content was reduced to below $2 \%$. Soybean meals and full-fat soybean were subjected to direct analysis, while raw soybean samples were subjected to heat treatments.

For this purpose, the first, soybean samples were taken into petri dishes in quantities of 50 grams. These petri dishes were numbered from 1 to 5 . No treatment was applied to the sample in first Petri dish. 2nd petri dish was kept at $100^{\circ} \mathrm{C}$, third at $110^{\circ} \mathrm{C}$, fourth at $120^{\circ} \mathrm{C}$ and fifth at $130^{\circ} \mathrm{C}$ in dry and unpressurized environment for 35 minutes.

The second sets of soybean samples were taken into petri dishes as in the first one and treated with water vapor and pressure in the autoclave at the same temperatures and time. For this sample also, no treatment was applied to the sample contained in petri dish 1 . The second petri dish was kept at $100^{\circ} \mathrm{C}$ (0.00 Atmosphere $)$, third at $110^{\circ} \mathrm{C}(0.40$ Atmosphere $)$, fourth at $120^{\circ} \mathrm{C}$ (1.00 Atmosphere) and fifth was kept at $130^{\circ} \mathrm{C}$ (1.72 Atmosphere) in the autoclave for 35 minutes.

\subsection{Chemical Analyses}

For determination of nutrients in samples, standard wet chemistry analysis were applied to all samples according to AOAC (1980). For the determination of trypsin inhibitor amounts in the samples, method used by Kakade et al. (1974) was applied. Urease activity, cresol red (CR) test estimations and amounts of raw nutrients were found by methods reported by Naumann and Bassler (1985).

\subsection{Statistical Analysis}

The statistical analysis performed by SPSS version 22 software (SPSS for Windows, version 22.0; SPSS Inc., 247 Chicago, IL).

\section{Results and Discussion}

Summary statistics of nutrient contents of the samples used in the study are presented in Table 1, trypsin inhibitory activity, urease activity and cresol red test results of intact samples are given in Table 2 . The results of trypsin inhibitor activity, urease activity and cresol red analysis after dry heat application and autoclave retention are given in Tables 3 and 4, respectively. 
Table 1

Nutrient contents of the samples used in the study, \%

\begin{tabular}{|c|c|c|c|c|c|c|c|c|c|}
\hline Sample & $\mathrm{N}$ & & $\begin{array}{c}\text { Dry } \\
\text { Matter }\end{array}$ & $\begin{array}{l}\text { Organic } \\
\text { Matter }\end{array}$ & $\begin{array}{l}\text { Crude } \\
\text { Protein }\end{array}$ & $\begin{array}{l}\text { Crude } \\
\text { Fiber }\end{array}$ & $\begin{array}{c}\text { Ether } \\
\text { Extracts }\end{array}$ & $\begin{array}{l}\text { Crude } \\
\text { Ash }\end{array}$ & $\begin{array}{c}\text { Nitrogen } \\
\text { Free } \\
\text { Extract }\end{array}$ \\
\hline \multirow{3}{*}{ Soybean } & \multirow{3}{*}{2} & Mean & 94.60 & 88.40 & 35.8 & 4.70 & 21.50 & 6.20 & 26.50 \\
\hline & & $\mathrm{SD}$ & 1.53 & 2.21 & 1.06 & 0.19 & 0.08 & 0.68 & 3.54 \\
\hline & & $\mathrm{CV}$ & 1.62 & 2.50 & 2.97 & 4.07 & 0.37 & 10.91 & 13.36 \\
\hline \multirow{3}{*}{ Soybean Meal } & \multirow{3}{*}{4} & Mean & 92.9 & 85.40 & 43.30 & 6.90 & 1.20 & 7.40 & 34.40 \\
\hline & & $\mathrm{SD}$ & 0.85 & 1.49 & 2.30 & 0.60 & 1.00 & 0.68 & 1.99 \\
\hline & & $\mathrm{CV}$ & 0.92 & 1.74 & 5.32 & 8.75 & 81.30 & 9.14 & 5.79 \\
\hline Soybean Meal (Imported) & 1 & & 92.79 & 86.53 & 39.50 & 7.84 & 0.42 & 6.26 & 38.47 \\
\hline Full-fat Soybean & 1 & & 95.18 & 87.96 & 37.13 & 5.49 & 19.13 & 7.22 & 26.21 \\
\hline
\end{tabular}

$\overline{\mathrm{SD}}=$ Standard Deviation; $\mathrm{CV}=$ Cofficient of variance

Table 2

Trypsin inhibitor activities, Urease activities and Creosol Red Test results in soybean meals and fullfat soybean

\begin{tabular}{lccccc}
\hline Sample & N & & $\begin{array}{c}\text { Trypsin } \\
\text { inhibitor } \\
\text { activities, } \\
\mathrm{mg} / \mathrm{g}\end{array}$ & $\begin{array}{c}\text { Urease activi- } \\
\text { ties, mg } \\
\text { N/g/minute }\end{array}$ & $\begin{array}{c}\text { Creosol } \\
\text { Red Test, } \\
\mathrm{mg} / \mathrm{g}\end{array}$ \\
\hline Soybean Meal & & Mean & 2.59 & 0.05 & 4.39 \\
& 4 & $\mathrm{SD}$ & 1.46 & 0.02 & 0.33 \\
Soybean Meal (Imported) & & $\mathrm{CV}$ & 56.37 & 40.00 & 7.52 \\
Full-fat Soybean & 1 & & 1.62 & 0.082 & 4.45 \\
\hline
\end{tabular}

$\mathrm{SD}=$ Standard Deviation; $\mathrm{CV}=$ Cofficient of variance

Table 3

Trypsin inhibitor activities, Urease activities and Creosol Red Test results of raw soybean sample (Soybean 1) autoclaved at different temperatures for 35 minutes

\begin{tabular}{lccc}
\hline Sample & $\begin{array}{c}\text { Trypsin inhibitor ac- } \\
\text { tivities, mg/g }\end{array}$ & $\begin{array}{c}\text { Urease activities, mg } \\
\text { N/g/minute }\end{array}$ & $\begin{array}{c}\text { Creosol Red Test, } \\
\mathrm{mg} / \mathrm{g}\end{array}$ \\
\hline Soybean 1 & 23.20 & 8.40 & 2.42 \\
$100{ }^{\circ} \mathrm{C}($ 0.00 Atmosphere) & 10.27 & 2.36 & 2.42 \\
$110{ }^{\circ} \mathrm{C}$ ( 0.40 Atmosphere) & 2.91 & 0.23 & 4.22 \\
$120{ }^{\circ} \mathrm{C}$ ( 1.00 Atmosphere) & 0.53 & 0.00 & 4.46 \\
$130{ }^{\circ} \mathrm{C}$ ( 1.72 Atmosphere) & 0.20 & 0.00 & 4.95 \\
\hline
\end{tabular}

This study was planned to determine the nutrient contents and feeding quality of soybean meals obtained from different part of Turkey (4 samples) and USA (1 sample) in 1988. In this study different temperature, humidity and pressure were applied to the raw soybean samples in laboratory conditions. TIA, UA and CR tests were used as quality control criteria in soybean to determine optimum conditions.

The crude protein and ether extracts values of raw soybeans examined in the study are given in table 1. These values obtained from the analysis are in similar with the values reported in the other sources (Crampton and Harris, 1968; Doğan, and Akyıldız, 1985). When the same table is examined, it is seen that the average of $43.30 \%$ crude protein value of the soybean meal produced in Turkey. Although the protein values of soybean meal are acceptable within normal limits according to some sources (Crampton and Harris, 1968; Morrison, 1961), it is given as $43.80-50-40 \%$ in some sources (Becker and Nehring, 1965; Doğan, and Akyıldız, 1985) remained lower than the values. On the other hand, the meal imported to Turkey $39.50 \%$ of the protein present was too small proportion of the meal produced. Except for the values of these samples, all other nutrient amounts of all studied samples were found similar to the values reported in the literature (Becker and Nehring, 1965, Morrison, 1961). 
Table 4

Trypsin inhibitor activities, Urease activities and Creosol Red Test results of raw soybean sample (Soybean 2) dry heated at different temperatures for 35 minutes

\begin{tabular}{lccc}
\hline Sample & $\begin{array}{c}\text { Trypsin inhibitor activi- } \\
\text { ties, } \mathrm{mg} / \mathrm{g}\end{array}$ & $\begin{array}{c}\text { Urease activities, mg } \\
\text { N/g/minute }\end{array}$ & Creosol Red Test, mg/g \\
\hline Soybean 2 & 30.00 & 8.87 & 3.03 \\
$100{ }^{\circ} \mathrm{C}$ & 27.12 & 8.87 & 3.07 \\
$110^{\circ} \mathrm{C}$ & 26.74 & 8.80 & 3.07 \\
$120^{\circ} \mathrm{C}$ & 26.29 & 8.75 & 3.22 \\
$130^{\circ} \mathrm{C}$ & 22.74 & 4.62 & 3.28 \\
\hline
\end{tabular}

The average TIA, UA and CR values of the soybean meal produced in Turkey used in the experiment, were found to be $2.59 \mathrm{mg} / \mathrm{g}, 0.05 \mathrm{mg} \mathrm{N} / \mathrm{g} /$ minute and $4.39 \mathrm{mg} / \mathrm{g}$, respectively. TIA, UA and CR values are determined as for imported soybean meal are respectively $1.62 \mathrm{mg} / \mathrm{g}, 0.082 \mathrm{~N} / \mathrm{g} /$ minute and $4.45 \mathrm{mg} / \mathrm{g}$. These values are in the same order for for full-fat soybean, $9.60 \mathrm{mg} / \mathrm{g}, 0.071 \mathrm{mg} \mathrm{N} / \mathrm{g} /$ minute and $4.43 \mathrm{mg} / \mathrm{g}$ (Table 2).

The TIA values of the soybean meal used in this study were found to be lower than the results of the TIA values of the samples used in another study conducted in our country (Yücelt, 1985). Similar results can be said in terms of UA values. Veltman et al. (1986) in 4 different soybean meal they added to the chick rations TIA values respectively; 6.5, 5.2, 4.4 and $2.9 \mathrm{mg} / \mathrm{g}$ : found the UA values in the same order as $0.19,0.11,0.06$ and $0.03 \mathrm{mg} \mathrm{N} / \mathrm{g} \mathrm{min}$.

TIA values in the products examined in the study are between 1-6 mg/g (Anonymous, 1978) reported as the availability limit for soybean products, except for $9.60 \mathrm{mg} / \mathrm{g}$ for full-fat soya. In addition, the results obtained were found below the maximum amounts given by Holmes (1987) and indicated as one tenth of the protein value. Accordingly, it can be said that enough heat is applied during the production of soybean meal, other than full-fat soya.

Urease activity in soybean and soybean meal is expressed in very different units in the literature. For this reason, it is not possible to compare the results of urease activity obtained with different methods in researches. As in this study, the normal use limit is reported between $0.05-0.50 \mathrm{mg} \mathrm{N} / \mathrm{g}$ min in the references that evaluate the activity determination as $\mathrm{mg} \mathrm{N} / \mathrm{g}$ min (Schiller, 1964; Holmes, 1987) In the research the average value of soybean meal produced in Turkey is $0.05 \mathrm{mg} \mathrm{N} / \mathrm{g}$ which is present as minutei is acceptable as an indication may be subjected to excessive heating process of some of these samples (Table 2).

The most important method used to check whether high temperature is applied in the production of soybean meal is the cresol red (CR) test. Compared to the results reported by Holmes (1987), according to the CR test results obtained (Table 2), it can be said that excess heat is applied to the soybean meals used in this study. However, according to another source (Schiller 1964) stating that the $\mathrm{CR}$ value can reach the upper limit of
$6.5 \mathrm{mg} / \mathrm{g}$, the CR test values obtained in this research can be accepted within normal limits. However, it is understood that the limit suggested by Schiller 1964 (Table 3) (Schiller 1964) was found to be experimentally considered in raw soybean with $130^{\circ} \mathrm{C}$ heat and 1.72 Atmosphere pressure (Table 3) (Schiller 1964).

Significant reductions in TIA and UA values of raw soybean were observed due to the increase in temperature and pressure in the autoclave (Table 3). In raw soybean, the TIA value of $23.20 \mathrm{mg} / \mathrm{g}$ decreased to $0.20 \mathrm{mg} / \mathrm{g}$ and UA value of $8.40 \mathrm{mg} \mathrm{N} / \mathrm{g}$ min decreased to $0.00 \mathrm{mg} \mathrm{N} / \mathrm{g}$ min when $130{ }^{\circ} \mathrm{C}$ heat and $1.72 \mathrm{At}-$ mosphere pressure applied. In dry heat application (Table 4), the TIA value decreased from $30.00 \mathrm{mg} / \mathrm{g}$ to $22.74 \mathrm{mg} / \mathrm{g}$ with increasing temperature. In dry heat application, decrease in UA test results was not considerable. When raw soybean samples were heated at $100^{\circ}$ $\mathrm{C}, 110^{\circ} \mathrm{C}, 120^{\circ} \mathrm{C}$ and $130^{\circ} \mathrm{C}$ under certain pressure in autoclave, the trypsin inhibitor was inactivated at rates of $55.73 \%, 87.46 \%, 97.72 \%$ and $99.14 \%$ respectively. In dry heat application at the same temperature, inactivation levels were realized at the rates of $9.60 \%$, $10.87 \%, 12.37 \%$ and $24.20 \%$. This is consistent with the results of the study, in which Scott, Sandholm, and Hockstets (Scott at al., 1976) indicated that trypsin inhibitors could not be sufficiently inactivated by dry heat application unless very high temperatures reached.

A decrease in TIA and UA values and an increase in $\mathrm{CR}$ test values were observed with increasing temperature (Table 3 and 4).

\section{Conclusions}

Finally, TIA and UA values in 5 soybean meals examined in this study were not too high to cause problems and this may be related to the high temperature applied during production. It can be said that as a result of high temperature application, the amount of usable protein and amino acids in the soybean meal will be significantly reduced and thus growth efficiency can be negatively affected in animals fed with such soybean meals.

\section{References}

Anonymous (1978). The estimation of trypsin inhibitor activity (TIA), In soy meals and soy products. 
Method no R/l/4b. Unilever Research Laboratory. Colworth

Anonymous (1988). Tarım Orman Köy İşleri Bakanlığl, Koruma Kontrol Genel Müdürlüğ̈̈ kayıtları. Ankara.

AOAC (1980). Official Methods of Analysis. (13 ${ }^{\text {th }}$ Eds. Dr George Latimer, Jr. Ed.) Association of Official Analytical Collaboration International.

Aygar Ö, (1987). Soya Küspesi Açığı ithal edilerek kapatılacak. Çiftlik Dergisi. 46, 12:30-31

Balloun SL, (1980). 'Soybean meal poultry Nutrition " The ovid Bell Press, Inc.; Fulton, Missouri.

Becker M, Und Nehring K (1965). Handbuch der Futttermittel' 'Zweiter Band. Verlag Paul Parey, Hamburg.

Crampton EW, Harris LE (1968). Applied Animal Nutrition. 2nd edition. W.H. Freeman and company San Francisco.

Doğan K, Akyıldız R. (1985). Soya:Üretimi, kalite kontrolü ve değerlendirilmesi. Yem Sanayicileri Birliği yayınları, Ankara.

Garlich JD (1987).Urease-trypsin inhibitor relationship in commercially produced soybean meals. Poultry Sci.66:suppl. 1.103.abs.

Hamerstrand GE, Black LT, Glover JD (1981). Trypsin inhibitor in soy products: Modification of the standard analytical procedure. Cereal Chem. 58(1): 42-45.

Holmes B (1987). Quality control of raw material and finished product in: " full fat Soya A Regional Conference 14-15, April, 1987,Milan Italy.

Kakade ML, Rackis JJ, Mc Ghee JE, Puski G (1974). Determination of trypsin inhibitor activity of soy products: A collaborative analysis of an improved procedure. Cereal Chem. 46:518-526

Koshiyama 1, Kikuchi M, Harada K, Fukushima D (1981). 2S Globulins of soybeans seeds. 1.İsolation and characterization of protein components. $J$. Agric. Food Chem. 28: 336-340.
Koshiyama 1, Kikuchi M, Fukushima D (1981). 2S Globulins of soybeans seeds:2. Physicocchemical and biological properties of protease inhibitors in $2 \mathrm{~s}$ globulins. J. Agric Food Chem. 29: 340-343.

Morrison FB (1961). 'Feeds and Feeding Abridged'. Claremont Ontario Canada the Morrison Publishing Company.

Liu K (2004). Soybeans as a Powerhouse of Nutrients and Phytochemicals and Edible Soybean Products in the Current Market. In Soybean as Functional Foods and Ingredients, K. Liu, (ed). pp.1-51, AOCS Press, Champaign, IL, USA

Naumann C, und Bassler R (1983). 'Die chemische Untersuchung von Futtermitteln. Methodenbuch. Bd. 3 mit Ergänzungslieferungen" 1983, 1988, 1993, 19972004 und 2006 VDLUFA. Darmstadt, Germany.

Schiller K (1964). Die wirkung von Dampferhitzen( Toasten) auf die biologische Eiweißwertigkeit von Sojaektraktionsschrot. Zeitschrift für Tierphysiologie Tierernährung und Futtermittelkunde. 19: 322330..

Scott ML, Sandholm M, Hockstetler HW (1976). Effects of antitrypsin and hemagglutinins in soybeans and other feedstuffs upon feed digestions in chickens. Proceeding Cornel Nutrition Conference. p 2225.

Taşcı R, Uçum İ (2018). Tarımsal Ekonomi ve Politika Geliştirme Enstitüsü (TEPGE) Soya 2017/2018 Durum Tahmin, Yayın no 304. Isbn: 978-605-2207$15-4$

Veltman JR, Blaine JR, Hansen J, Tdtanksley JR, Sandra S, Linton DK (1986). Comparison of nutritive value of different commercial soybean meals. Utilization by chicks in practical type rations. Poultry sci. 64:2314-2320

Yücelt Ö (1985). Çukurova bölgesinde üretilen soya fasulyesi tane ve küspelerindeki üreaz aktivitesi ve tripsin inhibitör faktör düzeylerinin saptanmas1 üzerine bir araştırma. Yüksek lisans tezi. Ç.Ü. Fen bilimleri Enstitüsü. 